\title{
$\bigcirc$ Boquirroto, irmão do Boca do Inferno
}

\section{Sônia van Dijck, UFPB}

Para Geraldo e Thom, que teriam amado o livro de Edilene e teriam mil histórias para contar sobre a Bahia.

Naquele tempo, dona Caçula, uma branquinha mignon, gordota e orgulhosa de sua ascendência portuguesa, apressava o passo, e lá ia eu, arrastada pela mão que ela segurava firme, pelo corredor do Elevador Lacerda, a caminho da fila de entrada em uma das cabines. Isso na cidade da Bahia. Cuíca de Santo Amaro estava em uma de suas performances, vendendo seus folhetos. Posso até jurar que ainda escuto minha avó sussurrando "vade retro" ou "t'esconjuro", para exorcizar de seus ouvidos (e talvez dos meus) os versos cantados por aquele homem baixinho, vestido de preto, com uns óculos que me pareciam de cego. Naquele tempo, nas casas de família, as mulheres pronunciavam à boca pequena $\mathrm{O}$ nome de Cuíca de Santo Amaro, sempre prestando atenção se havia criança por perto. Mas, lá estava eu, procurando entender as preocupações das mais velhas, e fiquei sabendo que, entre outras coisas, Cuíca também escrevia de encomenda, para escandalizar alguns fatos ou para denegrir reputações. E, com a mesma habilidade comercial com que aceitava a empreitada, podia negociar também a não divulgação dos folhetos já impressos, venden- do-os a quem estivesse interessado em não "cair na boca do povo", como se dizia naquele tempo. Negócio fechado, não se falava mais nisso, pois o poeta tinha suas normas e logo encaminhava seu talento, partindo para outra composição, que, certamente, fazia sucesso entre seus fiéis leitores (e leitoras, às vezes, clandestinas, nos quartos e salas íntimas dos casarões).

Naquele tempo, não me era permitido ler os folhetos que tanta preocupação e interesse causavam aos homens e às senhoras de bem, pois ninguém estava livre de ser cantado pelo bardo, se pisasse fora da linha dos bons costumes. Fico imaginando como seria se Cuíca de Santo Amaro tivesse conhecido os caminhos da web...

Coisas findas, que me foram revividas pela pesquisa de Edilene Matos: Cuica de Santo Amaro. O boquirroto de megafone e cartola (Rio de Janeiro: Manati, 2004, 136 p. Bahia com h, 4).

Edilene Matos, conhecida estudiosa da literatura popular, que já havia se dedicado ao artista baiano em Ele, o Tal Cuica de Santo Amaro (Salvador: Secretaria da Cultura e Turis- 
mo; EGBA, 1998), deu seguimento a suas pesquisas sobre essa figura emblemática que tem a cara do Brasil. Resultado: esse livro, em que presentifica um passado cultural e informa aspectos da cultura popular, presenteando o leitor com seu olhar mágico sobre a Bahia.

Sem dúvida, Edilene esteve mexendo em seu velho baú (tal como diz na pág. 15), à medida que desenvolveu a pesquisa. A pesquisadora reconstitui a figura do poeta de megafone de cartolina e em traje de gala carnavalizante, vendendo seus folhetos, fazendo propaganda na porta das lojas famosas na época, cunhando o slogan do mais chique alfaiate daqueles tempos na Bahia: "Adão não se vestia, porque Spinelli não existia"; e leva o leitor a sítios como a Baixa dos Sapateiros, Ladeira do Taboão, Baixa de Quintas, Estrada da Rainha, pisados por Cuíca de Santo Amaro, na cidade da Bahia, e por nós duas, ainda tão meninas, e, agora, revisitados por nós duas: uma como, pesquisadora; a outra, como leitora encantada pela memória tão bem narrada nesse trabalho de pesquisa.

Como cada cidade tem seus pontos e tipos característicos, Edilene nos oferece de volta endereços e figuras de época, das quais destaco a Mulher de Roxo, que marcava presença na porta da loja Sloper (na rua Chile), e que preenchia nosso imaginário com histórias muito bem relembradas pela autora. O turista que vai consumir a Bahia em pacote de férias, precisa saborear o roteiro do passado traçado por Edilene, para entender por que os baianos são tão ciosos de suas histórias e se emocionam em cada ladeira ou esquina. Sem falar no vapor de Cachoeira, que a gente pegava na Baiana, e que virou ruína no Porto dos Tanheiros, ritualmente tocado por Edilene, conforme confessa na pág. 32, sem saber que também celebrava minhas viagens...
Edilene foi ouvir a viúva dona Maria do Carmo Sampaio, para reencontrar Cuíca de Santo Amaro em sua dimensão particular e tentar explicar seu nome emblemático. Reconstitui o homem que usou seu talento profissionalmente, para sustentar a família. Reencontrou figuras da cultura baiana, na busca de testemunhos e trouxe de volta o falar baiano em sintagmas como "bocapio" (espécie de sacola de palha).

O resultado é uma conclusão (parcial, pois a paixão da pesquisadora pelo poeta vai gerar outras publicações, com certeza), que oferece ao leitor o clima do Primeiro Congresso Nacional de Trovadores e Violeiros, ano da graça de Nosso Senhor Jesus Cristo 1955, quando a "musa do Congresso", a folclorista Hildegardes Vianna, inspirou o vate de cartola a declamar versos de exaltação.

Mostrando forte embasamento teórico e crítico, a pesquisadora trata da literatura popular, de suas origens aos dias de agora, colocando em discussão, inclusive, o conceito de "literatura popular", apresentando várias classificações dessa produção, para formular sua proposta a respeito da obra de Cuíca de Santo Amaro, poeta que assina cerca de mil títulos de folhetos, sem se esquecer de tratar da questão dos direitos autorais (constante preocupação dos poetas populares - e não só dos populares...), para mostrar como ele buscava expedientes que asseguravam sua assinatura nos folhetos de sua autoria.

O livro, que está muito bem ilustrado com documentos como a certidão de nascimento e o atestado de óbito do poeta, além de capas de alguns folhetos e fac simile de originais, contempla também a questão da editoração e da criação das capas dos folhetos, dos cartazes usados por ele, de sua utilização performática da voz, e traz informa- 
ções relevantes, não só sobre as técnicas empregadas pelos capistas, mas também sobre um dos mais famosos artistas de folhetos: Sinézio Alves.

Imperdível é a parte em que a estudiosa apresenta alguns dos folhetos de Cuíca de Santo Amaro. O leitor fica sabendo até onde voava sua inspiração e o quanto podia ser irreverente sua língua, que tão bem manejava a palavra, mesmo que "em rimas pobres e imperfeitas", como diz Edilene, em versos que podiam causar a inquietação da tradicional família da época, tal como seu "irmão" o Boca do Inferno.

O livro interessa não só aos baianos, mas, sobretudo aos estudiosos de nossa memória cultural, que desejem conhecer a performance desse precursor dos recursos de multimídia, que deu lição até a mesmo a Chacrinha.

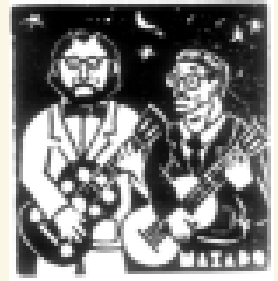

Santana: UEFS, v. 4, n 3, 2005, p. 266-268. 